\title{
Sir John R. Findlay, Bart., K.B.E., LL.D.
}

John Ritchie Findlay was born in Edinburgh on 13th January 1866, the eldest son of the well-known proprietor of The Scotsman, to whose enlightened liberality Scotland owes her National Portrait Gallery as well as the building which shelters her National Museum of Antiquities. His first schools were Mr Oliphant's in Charlotte Square and the Collegiate, flourishing institutions then, but both long since defunct. In 1879 he was sent to Harrow, to find among his companions boys destined to make their mark in such diverse ways as Stanley Baldwin and John Galsworthy. Here his predominantly scientific tastes led him naturally to the Modern Side. Nevertheless he was in Dr Butler's Sixth-a clear proof that his other intellectual qualities had not escaped his Headmaster's discerning eye. While he always retained a grateful recollection of what he had learned from Butler, he was still more conscious of a debt to M. G. Glazebrook, who had come to Harrow as an Assistant Master in 1878 and who was afterwards successively High Master of Manchester Grammar School, Headmaster of Clifton, and Canon of Ely.

In 1884 he matriculated at Balliol, where he at once began to specialise in Chemistry. Three years of steady work were rewarded by a comfortable First Class in the Final Science Schools. Such a measure of success would have satisfied most undergraduates. It would probably have satisfied him, had he not unwittingly convinced the College authorities that Oxford had something else to give him. Strachan Davidson, at that time Senior Dean, had been so struck by the capacity displayed in his essays on general subjects that he urged him to prolong his course for two years and read for Honours in Literae Humaniores. This was an arduous undertaking for one who had only made a beginning with Greek and had dropped it altogether at Harrow, and in the circumstances the extremely sound Second Class which he obtained in 1887 was really a remarkable achievement. When he went down, Strachan Davidson wrote that, although his handicap had robbed him of his due in the Schools, he was safe for a Double First in life.

Academic distinctions apart, his Oxford experience was a unique preparation for his future career, and he never ceased to look back on it with genuine pleasure. Permeated as it was by the subtly pervasive and unobtrusively powerful influence of Jowett, Balliol society was in 
those days nothing if not democratic, while it included an unusually high proportion of men who subsequently became prominent in the Church, in public life, in literature, or in scholarship. Findlay's range of acquaintance was exceptionally wide, not only because he was in residence for five years as against the normal three or four, but also because he pursued in turn two different lines of study. He was no athlete, and he was otherwise too unassuming to make himself a leader in any particular set. But he was universally liked and respected, as was shown by the widespread regret which his death evoked among those of his contemporaries who survived him. They could recall vividly his rather tall, spare figure with its slight stoop, as he moved in and out among them, keenly observant of all that was going on and occasionally giving rein to the quiet humour that seasoned his enjoyment of the human comedy around him.

Immediately on leaving Oxford he entered the office of The Scotsman. In order to gain a thorough knowledge of the machine which he was ultimately to control, he served a brief but exacting apprenticeship in each of the departments concerned with the production of a great newspaper. His father's death in 1898 thus found him well equipped for a position of responsibility. For a time he took an active share in the editorial work, particularly when the rigorous climate of Edinburgh drove the then editor, Mr Charles Cooper, abroad for the winter months. He was much interested, but the task proved too exacting. He was expected to play his part in the public life of Edinburgh, and under the growing pressure of day engagements his constitution stubbornly refused to adapt itself to the routine of night duty. Social obligations, too, began to be more insistent in their demands, especially after 1901, when his marriage to Harriet, the eldest daughter of Sir Jonathan Backhouse, laid the foundation of the singularly happy domestic life that was to be his until the end. In 1905 the appointment of a new editor brought him the relief which he desired. Others had already discovered his rare administrative gifts, and, while the welfare of The Scotsman always remained his first concern, now that he was comparatively free he responded to the call of public service with an unsparing devotion that was beyond all praise.

As early as 1899 he had succeeded his father on the Board of Manufactures, the old-time body that was responsible to the Government for the administration of the National Galleries and the National Museum of Antiquities. When the Board of Manufactures was superseded in 1907, he was appointed a member of the Board of Trustees which replaced it. He was reappointed at the beginning of each following quinquennium down to 1927 inclusive, and for the last eight years he was Chairman. 
The work was peculiarly congenial, for he had real taste and much more than the average layman's knowledge of art and things artistic. This was doubtless one of the reasons which prompted the late Sir James Guthrie to recommend that the Town Council should nominate him to represent the Lord Provost on the Board that was to manage the new College of Art, established in 1907. But the main motive behind the suggestion was an implicit confidence in his business ability and powers of organisation. The confidence was not misplaced. The flourishing condition of the College to-day is largely the fruit of his unremitting labours, extending over no less than twenty-three years. In 1911 and again in 1912 he was Treasurer of the Edinburgh Merchant Company, and in the next two years he held the office of Master, the highest honour that the business community of the City has to bestow. When difficulties emerged as the result of changes in the Scheme for the Superannuation of the Company's teachers and officials, he rose to the occasion and effected the necessary adjustment of conflicting interests quietly and without any ado. Membership of the Burgh Secondary Education Committee gave him further insight into the details of educational administration and lent added weight to his opinion when he was appointed to the Department's Advisory Council in 1924.

This tale of his local activities is far from complete. $\mathrm{He}$ was, for instance, a Director of the Royal Asylum at Morningside from 1905 onwards, while he was for twenty-six years on the governing body of the Royal Hospital for Sick Children and for eight years its Chairman. The business affairs of St Giles also claimed their share of his attention. Nor were the wider interests of the nation left without his assistance. As Vice-Chairman of the Ancient Monuments Board he was intimately concerned in the discussions that centred round the Scottish National War Memorial, and he was one of the original members of the Royal Fine Art Commission for Scotland. In 1915, when war-time exigencies made the question of housing accommodation at Rosyth an urgent one, he became Chairman of the Company that was called into being to cope with the situation. A year or two later, when the shortage spread over the whole country like the plague, he accepted the Chairmanship of another Housing Company which had Scotland for its province. Finally, in 1929 he agreed to the request of the Government that he should preside over the deliberations of a Committee which was set up to examine the problem of river pollution; but, before the inquiry had made much progress, the illness that was to prove fatal had laid its hand on him. He died on 13th April 1930. 
For several years previously his health had been none too good. Had he allowed that consideration to weigh with him, he would probably have given up much of his public work after 1922, when the death of Mr Law made it imperative that he should take a far more active part in the direction of The Scotsman. But he had an extraordinarily high sense of public duty, and he courageously endeavoured to carry the double burden, a burden made all the heavier by his extreme conscientiousness. This conscientiousness, however, contributed materially to his success as an administrator. The discipline of a newspaper office had taught him the value of method. He never willingly missed a meeting at which he felt that he could be helpful, nor did he ever attend one without mastering beforehand all relevant details of the matters to be discussed. Whether he was in the chair, therefore, or merely at the table, his ready command of the facts, his level-headedness, his even temper, and his thorough understanding of human nature made him invaluable. Sparing of speech, he could draft a minute or a resolution with admirable skill, and such was his tact that, even when he was leading the way, he seemed only to be following the suggestions of others.

So crowded a life left scant leisure for recreation or for intellectual pursuits; his very evenings were too often absorbed by preparation for meetings. His summer holiday was invariably spent on his country estate at Aberlour, to which he was warmly attached. In spring he sometimes went abroad, preferably in his later years to Italy, in the art treasures of which he revelled. Paris he had been familiar with from his boyhood, when his father sent him there for a vacation to study French. Subsequently he acquired a reading knowledge of German, and more recently he learned to while away his few idle moments with Italian novels. Behind all this, his well-stocked mind remained faithful to his first love, Science. As he was no mean mathematician, he was able to follow intelligently the astonishing advances which the twentieth century has witnessed in physics, in chemistry, and in astronomy. He was very early elected to the Royal Society of Edinburgh (1898). An invitation to join the Council had to be declined through sheer lack of time. But some years ago he gave the Fellows a glimpse of what he was doing in his own particular corner of the field. Gifted with an uncommonly clever pair of hands, he knew good craftsmanship when he saw it, and this, combined with his fine taste, enabled him to build up gradually the remarkable collection of astrolabes and sun-dials which his widow and son have placed on loan in the Royal Scottish Museum. To him, however, they were not mere curios, like the pieces of old furniture and of old 
silver of which he was so excellent a judge. He was deeply read in the literature of the subject, of which he had formed an extensive library; and almost the only publication which he produced under his own name was a paper, read to the Royal Scottish Geographical Society, in which he described how the invention of striking clocks had revolutionised the method of reckoning time. When there was a danger lest the Lewis Evans collection of scientific instruments should be lost to Oxford, his generosity was in no small degree responsible for providing the permanent home that was needed, and he also presented to the University the silver microscope that had belonged to George III. Nearer home it will not be forgotten how he averted a deadlock between the Managers of the Royal Infirmary and the Merchant Company by a timely donation of $£ 10,000$.

In 1902 he was made a Deputy Lieutenant for the City of Edinburgh, in 1917 a K.B.E., in 1922 an Honorary Royal Scottish Academician and an LL.D. of the University of Edinburgh, in 1925 a Baronet, and in 1928 Lord-Lieutenant of Banffshire. But these honours left the essential simplicity of his nature entirely unaffected. Writing of him as he was at Harrow and Oxford, Mr O. M. Dalton, formerly of the British Museum, says: "I seem to remember him less for what he did than for what he was-one from quite early days sober in judgment, but keenly alive to the humorous side of things; not demonstrative, but an unselfish and most loyal friend, always considerate and courteous in the widest sense of the term to people in all walks of life." To the very last these qualities attended him, unchanged and unshadowed. Sit illi terra levis.

G. M. 